\title{
MASTER
}

\section{THE APPLICATION OF INTERSTATE \\ COMPACTS TO ENERGY-FACILITY SITING}

American Management Systems, Inc,

\author{
Prepared For: \\ U.S. DEPARTMENT OF ENERGY \\ ASSistant SECRETARY FOR ENVIRONMENT \\ OFFICE OF TECHNOLOGY IMPACTS \\ POLICY ANALYSIS DIVISION
}

OCTOBER 1979

Under Contract Number: DE-AC02-79EV10274

AMERICAN MANAGEMENT SYSTEMS, INC. 


\section{DISCLAIMER}

This report was prepared as an account of work sponsored by an agency of the United States Government. Neither the United States Government nor any agency Thereof, nor any of their employees, makes any warranty, express or implied, or assumes any legal liability or responsibility for the accuracy, completeness, or usefulness of any information, apparatus, product, or process disclosed, or represents that its use would not infringe privately owned rights. Reference herein to any specific commercial product, process, or service by trade name, trademark, manufacturer, or otherwise does not necessarily constitute or imply its endorsement, recommendation, or favoring by the United States Government or any agency thereof. The views and opinions of authors expressed herein do not necessarily state or reflect those of the United States Government or any agency thereof. 


\section{DISCLAIMER}

Portions of this document may be illegible in electronic image products. Images are produced from the best available original document. 
THE APPLICATION OF. INTERSTATE COMPACTS TO ENERGY-FACILITY SITING

American Management Systems, Inc.

Prepared For:

U.S. DEPARTMENT OF ENERGY

Assistant Secretary. for Environment

Office of Technology Impacts

POLICY ANALYSIS DIVISION

October 1979

Under Contract Number: DE-AC02-79EV10274

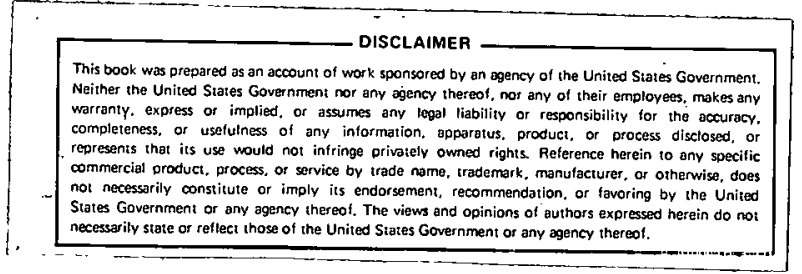


This paper examines the nature and function of interstate compacts I/ in the U.S., and explores their potential for helping to resolve environmental issues related to the siting and permitting of energy producing facilities (e.g., power plants, synthetic fuel plants). Elements of state energy facility siting programs are identified, and the ability of interstate compacts to assist in accomplishing each element is analyzed. This analysis provides the basis for assessing the potential capabilities and limitations of compacts, and for initially estimating the possible benefits of a Federal program to promote the formation of compacts to address regional energy siting issues.

\section{A. Regional Impacts of New Energy Facilities}

A significant aspect of bringing on line new energy producing facilities is the need for planning and siting of such facilities on a regional basis. There are several reasons for expanding the traditional state-by-state approach to energy facility siting to a more regional, multi-state approach. First, many large new power plants and their associated facilities impact upon resources in several nearby states. The most common example is the pollution or consumption of water, which has an effect on downstream states. However, recent environmental research into phenomena such as migratory air pollution and acid rainfall has demonstrated that the environmental impacts of large power plants can be far more widespread and prolonged than was previously assumed, and thus can have significant impacts upon neighboring states. Finaliy, the products of energy facilities (e.g., electricity, gasoline, synthetic fuels) are often distributed across several state lines, requiring extensive interstate transport facilities (e.g., gas pipelines, coal slurry pipelines, transmission wires), and therefore also pose potential problems.

There are indications that the regional impacts of energy facilities will be heightened in the future. First, future energy development may include centralized energy centers or "energy parks" built according to the "flexbig" model.2) These energy centers would have many small units (e.g., about 500 . 1 W

II Interstate compacts are formal agreements enacted by the Governors and legislatures of several states, and approved by the U.S. Congress. Compacts may address a variety of issues, such as allocating rights to a resource shared by several states (e.g., a river), resolving an interstate boundary dispute, or establishing an interstate agency to conduct planning or regulatory activities.

2/ The "flexbig" concept is currently being studied by several engineering and electric utility firms. The origin and basis of the concept is discussed in Wiggins, Wormhoudt, and Schroeder, "Issue Paper: Flexibility of Scale in Large Conventional Coal-Fired Power Plants," prepared for DOE under Grant No. EY-76-S-03-PA284, December 1978. 
each) which, in total, comprise a very large generating capacity. The potential environmental impacts of these energy centers, as well as the power they produce, would be distributed over a multi-state area. The emergence of a sizeable synfuels industry would present a similar situation. Large high-Btu gasifiers, liquefaction plants, and oil. shale retorts would tend to be concentrated in areas. where the coal and shale supplies are most plentiful, particularly the relatively arid and sparsely populated regions of the northern Rockies. These facilities would add to the existing strain on the resources of this region.

Because of the increased recognition of the broader impacts of energy facilities, some s.tates are beginning to take more of an interest in the planning and siting of facilities in neighboring states. At present, however, the regulation of the siting of energy facilities is generally carried out on an individual state basis. Little or no opportunity exists for neighboring states to participate formally in these decisions outside of the public hearings process.

The growing sensitivity to regional energy issues should increase the degree of multi-state participation. The following cases illustrate how states are attempting to influence the siting process in neighboring states:

- In compliance with new regulations under the National Environmental Policy Act, DOE held an early "scoping" meeting in June 1979 near Horgantown, WV to elicit public comment on the planned location of a coal liquefaction demonstration plant in that area. At the meeting, a representative from the Pennsylvania state government objected to the facility's location on the bas is of migratory air pollution which would be carried into Pennsylvania by prevailing wind patterns.

- Representatives from the Commonwealth of Kentucky have recently threatened legal action to block an Indiana decision granting a license for an Indiana Public Service Co. nuclear plant which would be located on the Ohio river less than 50 miles upstream from Louisville.

- The New York Harbor. Interstate Sanitation Commission is representing the State of New Jersey in a lengthy public hearing concerning the location of a new Consolidated Edison $\mathrm{Co}$ : generating plant on Staten Island. Although the hearing is being conducted by the New York Public Service Commission, which will retain final decision-making authority, testimony on the plant's impact on the neighboring New Jersey environment is being considered.

The problem, as illustrated by these cases, is that this approach by neighboring states tends to be an adversary relationship which can result in lengthy delays, rather than a more cooperative, constructure approach to the siting issue. An interstate compact might provide the mechism for facilitating more constructive resolution of disputes. 


\section{Potential Benefits of Compacts for Facility Siting Programs}

An assessment of the potential benefits of interstate compacts on siting decisions and procedures can best be done by identifying the functions involved in the siting of a facility, examining the experience of existing compacts on problems in the context of these functions, and applying these findings to the siting of energy facilities.

\section{Basic Functions of Siting Programs}

While some states use more sophisticated approaches than others, most siting programs include:

a. Monitoring and Research: Siting decisions require technical analyses which must be supported to some extent by basic research, the most common type being environmental research. This includes gathering data on air and water quality, drainage and wind patterns, plant and animal life and other variables. other reserach is directed at developing and evaluating new pollution control technologies and monitoring devices. Although applicants for siting permits have generally been responsible for gathering data to support their application, the states themselves (e.g., California, and Michigan) are beginning to conduct more reserach related to site-selection activities.

b. Resource Planning: Resource planning includes, among other things, land-use planning, urban planning, and water rights allocation. State and local planning agencies use data on natural resources and ecosystems in making decisions on the suitability of areas of the state for various types of development, or the allocation of scarce resources (e.g., water in the Colorado River basin).

c. Standard-Setting: The most substantive environmental regulatory activity carried out by most states is the promulgation of legislation and regulations establishing pollution control standards for facilities located within the state. These standards may constitute state implementation of a program mandated by Federal legislation (such as State Implementation Plans established under $\$ 110$ of the Clean Air Act) or result from state initiatives. Applicants for facility siting permits must demonstrate that the proposed facility will comply with applicable state environmental standards.

d. Permitting: Reviewing applications and granting permits is a major function of any facility siting program. Most programs require applicants to submit detailed descriptions of their proposed facility and its expected environmental impacts. These applications are reviewed by the state permitting agency and 
may be forwarded to other government agencies, private groups and individual citizens for comment. In addition to the authority to simply grant or deny a permit, most agencies can also attach certain conditions to the award of a permit, such as the requirement that specific control equipment be installed or that effiuent discharges be located at specific points along a waterway.

e. Enforcement: Although enforcement is more applicable to "operating" permits than to siting permits, a workable enforcement program is essential to the overall effectiveness of the process. Enforcement generally consists of two activities, compliance monitoring and assessing penalties. Compliance monitoring can include reviewing reports submitted by facility operators, conducting on-site inspections, and operating sophisticated sampling and monitoring equipment. Assessment of penalties, such as show-cause orders, violation notices or fines, may be carried out by a separate legal agency of the state government."

These five functions may be carried out by one or several offices within a. state government. Some of the activities (particularly basic research and standard-setting) may be supported by funds or guidance from the Federal government.

2. Effects of Existing. Compacts on Siting Programs

Using the above framework, the effect of existing interstate compacts on each siting program function can be examinad.

Table 1 outlines the existing interstate compacts investigated in this study. Although none of these compacts have been established for the purpose of expediting energy facility siting, many of them conduct some of the five activities involved in siting programs. The discussion which follows is based on documents and interviews provided by personnel from the interstate agencies which manage these compacts. If

a. Monitoring and Research: Most existing interstate agencies conduct some form of monitoring and research, primarily monitoring pollutant levels in the environmental media (usualiy water) covered by their mandate. The Early Warning Organics Detection System developed by ORSANCO to detect concentrations of toxic pollutants in the onio River, and the extensive natural systems data base compiled by the

II The term "compact" is used throughout this paper to refer to the formal legal agreement between the member states. An "interstate agency" is the organization created to implement the terms of the compact. 
TABLE 1

Interstate Compacts and Agencies Examined

\begin{tabular}{|c|c|c|c|c|}
\hline FULL NAME & ACRONYM & YEAR FORMED'- & MEMBER STATES $\underline{2}$ & PURPOSE \\
\hline Colorado River Compact & CRC & 1922 & $\begin{array}{l}A Z, C A, C O, N M, \quad H V, \\
U T, W Y\end{array}$ & Water Allocation \\
\hline $\begin{array}{l}\text { New York Harbor Inter- } \\
\text { state Sanitation } \\
\text { Commisstion }\end{array}$ & NYHISC & 1935 & $\mathrm{CT}, \mathrm{NJ}, \mathrm{NY}$ & $\begin{array}{l}\text { Water Pollution } \\
\text { Control }\end{array}$ \\
\hline $\begin{array}{l}\text { Ohio River Valley Water } \\
\text { Sanitation Commission }\end{array}$ & ORSANCO & 1939 & $\begin{array}{l}I L, I N, K Y, N Y, O H, \\
P A, V A, W V\end{array}$ & $\begin{array}{l}\text { Water Pollution } \\
\text { Control }\end{array}$ \\
\hline $\begin{array}{l}\text { New England Interstate } \\
\text { Water Pollution Control } \\
\text { Commission }\end{array}$ & NEIWPCC & 1947 & $\begin{array}{l}\text { CT, MA, ME, NH, NY, } \\
R I, V T\end{array}$ & $\begin{array}{l}\text { Water Pollution } \\
\text { Control }\end{array}$ \\
\hline Great Lakes Commission & GLC & 1955 & $\begin{array}{l}I L, I N, M I, M A, N Y, \\
O H, P A, W I\end{array}$ & $\begin{array}{l}\text { Planning \& Infor- } \\
\text { mation Services }\end{array}$ \\
\hline $\begin{array}{l}\text { Tennessee River Basin } \\
\text { Water Pollution Control } \\
\text { Commission }\end{array}$ & TRBWPCC & 1955 & $A L, G A, T N$ & $\begin{array}{l}\text { Water Pollution } \\
\text { Control }\end{array}$ \\
\hline $\begin{array}{l}\text { Tahoe Regional Planning } \\
\text { Agency }\end{array}$ & TRPA & 1969 & $\mathrm{CA}, \underline{3 /} \mathrm{NV}$ & Land-use Planning \\
\hline
\end{tabular}

I/ Year the compact was first formed. Many of the compacts have been revised over time and some claim different dates of origin.

2/ State codes are the 2-letter postal codes.

3/ As of 1979; California has withdrawn support from TRPA.

TRPA to help categorize soils in the Tahoe Basin are two examples of large-scale research projects which were undertaken to support standard-setting, and which probably would not have been attempted by the member states themselves. Most of the monitoring and research conducted by interstate agencies provides effective support for state or interstate planning or rulemaking, and is partially funded by Federal agencies.

b. Resource Planning: Although the planning for or allocation of natural resources is the principal mandate of some interstate agencies (e.g., TRPA, CRC), not all interstate agencies perform this function. The agencies which are most effective at resource planning are those that have been granted the authority to implement and enforce their plans. Other agencies lack this authority, and can only make recommendations to member state governments. 
c. Standard-Setting: Promulgating standards is one of the principal responsibilities which states are most reluctant to delegate to an interstate agency. The zoning ordinances established by TRPA and the water quality. standards set by the NYHISC are exceptions, in that their mandates are unusualiy strong for this function. Although these two agencies have been effective in promulgating and enforcing standards, their applicability has been limited to a specific and relatively small geographic region. The ORSANCO case, where the interstate agency can only recommend that member states adopt consistent water quality criteria, is more typical.

d. Permitting: In general, interstate agencies lack both the mandate and the resources to assume responsibility for issuing permits or expediting the permitting process conducted by member states. While many states-accept support from interstate agencies for environmental monitoring and research, or consider their recommendations on a case-by-case basis, few have been willing to include permitting authority in a compact. ORSANCO, which does have the authority to issue National Pollutant Discharge Elimination System. (NPDES) permits for a limited number of facilities on the Ohio River itself, is a notable exception.

e. Enforcement: It is more common for interstate agencies to conduct compliance monitoring (often as part of a broader environmental quality monitoring program) than to take direct enforcement actions such as assessing fines or issuing shutdown orders. However, many interstate agencies become involved in compliance-related lawsuits with developers, utilities, and local governments. Although interstate agencies have generally been very successful in having enforcement actions upheld in court, there is little cooperation in legal proceedings between them and member states, and in some cases (e.g., TRPA) states have filed suit against an interstate agency which they are supporting.

In summary, the experience of existing compacts shows that states have been more willing to establish interstate agencies to conduct background research and monitoring activities than to delegate substantive authority for either rulemaking or permitting of individual facilities. Interstage agencies have generally been effective in conducting the research and monitoring. The limited information available on the application of compacts to other activities indicate that interstate agencies can conduct effective, ongoing programs for standard-setting and permitting, but only if they are given the necessary authority and resources.

This analysis of existing compacts also provides a basis for drawing conclusions concerning the characteristics of effective compacts. The more effective interstate compacts generally exhibited three characteristics: 
- Consistent State Goals and Policies: The states in the more effective compacts shared reasonably consistent priorities and goals with respect to economic development and environmental protection. As shown in the Lake Tahoe experience, the geographic proximity of states is not a sufficient basis for conducting regional environmental planning. On the other hand, states such as the ORSANCO member states, which begin with somewhat consistent policies, have made more progress in resolving disputes and accomplishing their objectives.

- Strong and Clear Mandate: Compacts cannot function effectively without a clear, unambiguous purpose; and the most effective compacts (e.g., New York Harbor, ORSANCO) are those which concentrate resources on fulfilling a clear mandate, however limited.

- Technical Staff Expertise:-Given the need for an interstate agency to conduct substantive research and planning and to resolve disputes, its technical credibility must be substantial. The more effects compacts generally were able to attract and maintain a competent technical staff which could address complex questions and conduct sound anaiyses.

\section{Potential Benefits of Compacts for Energy Facility Siting}

The discussion above suggests that existing compacts or new compacts could play a role in coordinating and facilitating energy facility planning and siting: There are, however, both legal and political constraints on how much authority states can and will delegate to interstate agencies. In general, states seem more willing to delegate authority to an interstate agency to conduct procedural aspects of facility siting (such as research, monitoring, and reviewing perinit applications) than to assume more substantive responsibility (i.e., standard setting and the making of final decisions on granting permits). This section will discuss the potential contribution of interstate compacts to each element of facility siting programs, assuming that states would be willing to cede authority in each case.

a. Monitoring and Research: Compacts offer a promising opportunity to expand the scope and.improve the efficiency of the basic environmental and technical research which is marked in the siting process, and which is now conducted by individual states. Where rivers or harbors border on several states in a region, compacts which allow water quality monitoring and research to be conducted on an interstate basis can efficiently produce more consistent and useful data. The same situation exists with respect to air quality monitoring.

Existing compacts now perform closer to their potential in this area than in other areas of siting programs.

b. Resource Planning: As noted, most compacts have been established to carry out resource planning or allocation. In regions where these activities are currently being done on an individual state basis, an interstate agreement allowing regional planning would represent an improvement in efficiency, if not in quality as well. 
This would seem to be particularly true for energy facility planning. Regional allocation of scarce resources required by energy facilities would be an innovative and important activity which could be more effectively accomplished through interstate compacts.

c. Standard-Setting: Although states have been reluctant to relinquish standard-setting authority, compacts could potentially make significant contributions toward promoting consistency among environmental standards in a region. Disputes now being raised over potential migratory air and water pollution associated with planned facilities could be averted or defused by preventing the situation of one state's standards allowing construction of a plant which produces pollution transported into neighboring states with more stringent regulations. Compacts, while probably not having the authority to. set common standards, would provide a formal mechanism for discussing and recommending common standards.

d. Permitting: States are nearly as reluctant to delegate responsibility to issue permits ( $i . e$, to make the decision to issue the permit) as they are to delegate standard-setting authority. However, there are many opportunities within the permitting function for interstate cooperation in the area of facilitating the permit review process. Joint hearings by agencies from different states to review a proposed project, and agreements committing agencies from several states to a common review and decision-making schedule are examples of interstate cooperation which should speed up the review. It is less likely that an extensive number of compacts would be granted the authority to issue permits in the member states. If this should occur, the process would be further expedited.

e. Enforcement: Despite the greater importance of the enforcement function to granting operating permits than to regulation of facility siting, enforcement plays an integral role in any regulatory program. In the few cases where standard-setting or permitting responsibilities have been delegated to an interstate agency, enforcement authority has also usually. been delegated. Although it seems logical for an agency to enforce its own standards, many interstate agencies have limited funds and staff to perform this function. Consequently, their resources would have to be supplemented by personnel from state regulatory agencies or Attorney Generals! staffs. While delegating enforcement authority to an interstate agency may ensure that compliance monitoring, inspection, and legal enforcement activities are carried out consistently within a region, the substantial resources required to carry out these tasks must also be provided. 
Although there is considerable potential benefit from interstate compacts, much of this potential must be qualified by consideration by which functions states are actually willint to delegate. Interstate agencies have shown themselves capable of conducting state-of-the-art research and monitoring, and states seem willing to support them in this area, The ability of interstate agencies to conduct effective planning and standard-setting depends largely on the states' willingness to delegate resources and authority to enforce their plans and statutes. In the areas of standard-setting and permitting, compacts will have limited potential for promoting consistent standards or expediting the permit process as long as states are only willing to delegate authority to conduct the procedural aspects of these functions (reviewing and commenting on permit applications, conducting background research to support new standards) rather than more substantive authority (granting permits and enacting standards).

\section{Considerations for Federal Involvement}

As shown above, there are benefits to be gained from involving interstage compacts. in energy facility siting. The Federal government could play role in encouraging and supporting such compacts; however, care must be exercised in determining what types of Federal support would be effective. This section discusses two aspects of the Federal support issue: (1) the fundamental conditions necessary to make a compact effective and therefore worth. supporting, and (2) the leverage which the Federal government possesses to encourage compacts to carry out various activities.

\section{Criteria for Support}

To help ensure that Federal support of interstate compacts is productive Federal agencies should adopt selected minimal criteria to be applied to compacts seeking Federal support. These prerequisite criteria correspond to the three conditions of effective compacts outlined earlier.

a. Consistent Goals and Policies: States belonging to either an existing or new interstate compact receiving Federal support to conduct energy facility siting activities should share reasonably consistent priorities and goals with respect to economic development and environmental protection.

b. Strong and Clear Mandate: The purpose of each compact should be clear and well-understood by all member states, and spelled out clearly in the compacts charter. To ensure that compacts can - effectively carry out energy tacility siting tasks, they should be urged to provide as much responsibility as possible for implementing their policies and plans through the standard-setting, permitting, and enforcement activities.

c. Technical Staff Expertise: Interstate compacts must include enough to be capable of carrying out adequate research, monitoring, and planning activities. 


\section{Potential Federal Role}

Because the U.S. constitution requires that Congress approve all interstate compacts, the Federal government is necessarily somewhat involved in the creation and direction of all interstate agencies. However, there are some interstate activities which the Federal government may be better able to encourage than others, and these are not necessarily the same activities where compacts could produce the greatest potential benefit. Therefore, the limits on Federal leverage in various areas should be considered.

An examination of existing compacts shows that states have been very willing to accept Federal support to conduct basic monitoring and research into environmental or technical issues. The Federal government (sometimes acting through Federal court decisions) has also been successful in promoting planning for or allocation of interstate resources (e.g.., water use allocation by the CRC, water quality management by ORSANCO). However, since the Federal government is legally prohibited from direct intervention in the areas of internal state programs and regulations, federal leverage in the areas of standardsetting, permitting, and enforcement programs is not as strong.

Given that interstate agencies do have some potential for addressing energy facility issues, DOE or other Federal agencies may wish to adopt a policy of encouraging new and existing compacts to take advantage of this potential. There are three general mechanisms which Federal agencies could use to encourage and support compacts oriented toward energy facility siting.

a. Federal Funds: A program could be established to provide financial assistance to interstate agencies which conduct planning and permitting of energy facilities. There are several somewhat similar ongoing programs (e.g., Section 106 of Clean Air Act, Section 208 of Federal Water Pollution Control Act) which provide funds to interstate agencies to support activities in the areas of air quality planning and waste management.

b. Federal Technical Assistance: Federal agencies, perhaps' acting through Federal Regional Councils or Regional Offices, could provice educational services or technical support to interstate agencies, or groups of states thinking about forming compacts, involved in the area of energy facility siting. Examples would include furnishing information from DOE Regional Offices on new energy facilities planned in an area, and providing information from Department of the Interior agencies such as the U.S. Geological Survey, Bureau of Land Management, and Fish and Wildlife Service on natural characteristics such as drainage patterns, land use and wildlife, which could support environmental impact analyses. 
c. Modification of Relevant Regulations: Federal agencies have the authority under Section 110 of the Clean Air Act and similar sections of other legislation to dictate the contents of accpetable state implementation plans (SIPS). Under this authority, requirements could be included that in some situations, states must establish interstate organizations to address energy and environmental issues on a regional basis.

Within each of these options, decisions would have to be made concerning the degree to which Federal authorities wish to dictate specific functions which compacts must undertake in order to receive support. 
Management Summary . . . . . . . . . . . . . . i

I. INTRODUCTION $\cdots \cdots \cdots \cdot \ldots \ldots \ldots$

A. Purpose. . . . . . . . . . . . . . . . . . 1

B. Background . . . . . . . . . . . . . . . . . . 1

C. Framework for Analysis . . . . . . . . . . . . . . 4

o.. Organization ............... . . 6 .

II. BASIC CONCEPT OF AN INTERSTATE COMPACT . . . . . . . . 7

A. Purpose. . . . . . . . . . . . . . . . . 7

B. Constitutional Guidelines. . . . . . . . . . . 7

C. Definition and Membership. . . . . . . . . . . 8

III. SURVEY OF EXISTING COMPACTS. . . . . . . . . . . . . . . . 9

A. Types and Purposes of Compacts Reviewed. . . . . . . . 9

1. Usage Compacts . . . . . . . . . . . . . . 9

2. Quality Compacts ............ 10

B. Common Traits of Compacts. . . . . ...... 13

1. Membership and Organization. .......... 14

2. Funding. . . . . . . . . . . . . . . . 15

3. Decision-Making Procedures ........... 16

4. Role of the Federal Government....... . . 16

C. Functions Performed by Interstate Compacts . . . . . . 18

1. Monitoring and Research. . . . . . . . . . . 20

2. Resource Planning. . . . . . . . . . . . 20

3. Standard-Setting . . . . . . . . . 20

1. Permitting.............. . . 21

5. Enforcement. . . . . . . . . . . . 21 
IV. CASE STUDIES OF THREE COMPACTS. . . . . . . . . . . 23

A. The Ohio River Valley Water Sanitation

Commission (ORSANCO). . . . . . . . . . . 23

1. Purpose and History. . . . . . . . . . . . . 23

2. Organization. ............. . . 24

3. Funding and the Federal Government's Role...... 24

4. Current Activities. . . . . . . . . . . 25

5. Effectiveness............. . . 26

6. Conclusions............ . . . 27 27

B. The Tahoe Regional Planning Agency. . . . . . . . . 28

1. Purpose and History ............... 28

2. Organization. . . . . . . . . . . . . 29

3. Funding and the Federal Role........... 30

4. Current Activities. . . . . . . . . . . . . 30

5. Productivity and Effectiveness. . . . . . . . 32

6. Conclusions.............. . . . 33

C. Interstate Sanitation Commission. . . . . . . . . 34

1. Purpose and History .............. . . 34

2. Organization. ................. 34

3. Funding and the Federal Government's Role...... 35

4. Current Activities. . . . . . . . . . . . 35

5. Effectiveness............... . . 37

6. Conclusions............... . . . 37

V. POTENTIAL UTILITY OF COMPACTS FOR FACILITY SITING . . . . . . 39

A. Basic Conditions for Effective Compacts... . . . . 39

1. Reasonably Consistent Goals and Policies. . . . . . 39

2. Clcar and Strong Mandate. . . . . . . . . . 39 
3. Independent Organizational Structure. . . . . . . 40

4. Technical Staff. Expertise. .......... 40

5. Adequate and Flexible Funding........... . 41

B. Potential Benefits of Compacts for Facility Siting Programs 41

1. Basic Research. . . . . . . . . . . . . . . 41

2. Resource Planning. . . . . . . . . . . . . 42

3. Standard-Setting. ............ 42

4. Permitting. . . . . . . . . . . . . . 42

5. Enforcement .............. . . 43

VI. FEDERAL INVOLVEMENT IN INTERSTATE COMPACTS. . . . . . . . 45

A. Criteria for Federal Support. . . . . . . . . . 45

1. Consistent Goals and Policies........... 45

2. Clear and Strong Mandate. . . . . . . . . . . . . . 45

3. Technical Staff Expertise........... . 46

8. Potential Federal Role................. 46

1. Federal Funds.................. . 47

2. Federal Technical Assistance. . . . . . . . . . . . . 47

3. Modification of Relevant Regulations. . . . . . . 48

BIBLIOGRAPHY. . . . . . . . . . . . . . . . . 49 


\section{INTRODUCTION}

\section{A. Purpose}

This paper examines the nature and function of interstate compacts in the United States, and their potential role in addressing problems related to the siting and permitting of large new energy facilities.

\section{B. Background}

Two developments suggest that innovative approaches will be required to help deal with the licensing and permitting of new energy facilities. First, the demand for energy in the U.S. creates a need for additional energy facilities, both to replace old plants and to contribute to additional energy supplies. Second, the current trend among utilities is toward larger power plants. Large facilities are believed to offer certain eceonomies of scale, including reducing the number of regional siting decisions, allowing quantity discounts in the purchase of fuel from mining companies and other suppliers, and creating transportation economies which become more important as environmental constraints may result in new facilities being sited farther from electricity users.

One of the changes brought on by this shift toward large new energy facilities is the need to expand the traditional state-by-state regulation of facility siting to a more regional, multi-state scope. There are moral reasons for this:

- Large new facilities may draw on resources provided by several states. A common example is the consumption of water from a river which forms the boundary between two states or which flows into other states downstream. Other resources which a facility may impact on from several states include air, labor, and transportation facilities (e.g., roads, railroads). 
- There is now a greater awareness of the regional nature of environmental impacts. For example, research into environmental phenomena such as migratory air pollution and acid rain has demonstrated that the environmental impact of large power plants can be more widespread and prolonged than was previously believed. Advanced techniques such as satellite photography of prolonged air pollution incidents have established that pollution produced within a small area can migrate across state and regional boundaries without being significantly dimimished.

- The products of energy facilities (e.g., electricity, gasoline, synthetic fuels) are often distributed across state lines. This has led to increasing development of energy transportation facilities (e.g., oil and gas pipelines, coal slurry pipelines, transmission wires) which span a multi-state region.

There are several indications that there will be additional regional energy facility impacts. First, future energy development may include the construction of central "energy parks" built according to the "flexbig" model. These facilities would be characterized by several relatively small units comprising a large total generating capacity. These large "parks" would have broad environmental. impacts, and the power they produce would likely be distributed over a multi-state area. II

The expected growth of synthetic fuel production during the next decade will have interstate impacts. Large high-8tu gasifiers, coal liquefaction plants and oil shale mines and retorts will likely be concentrated near coal and shale supplies. These resources are found mainly in the relatively arid and sparsely-populated areas of the northern Rockies, where large new facilities would have to draw on the scarce resources of the entire multi-state region.

For a further explanation of the flexbig model, see Wiggins, Wormhoudt, and Schroeder, "Issue Paper: Flexibility of Scale in Large Conventional CoalFired Power Plants," prepared for DOE under Grant No. EY-76-S-03-PA284, December, 1978. 
States are becoming increasingly sensitive to the regional aspects of energy facility development. Although facility siting is generally carried out on a state-by-state basis, hearings and other elements of the facility siting process which are open to the public provide an opportunity for states to play a part in approving the construction of facilities located in neighboring states. In the following cases, states have anticipated the regional environmental impacts of energy facilities located in adjacent states and have sought to influence the siting process:

- In compliance with new regulations under the National Environmental Policy Act (40 CFR 1501.7), DOE held an early "scoping" meeting in June 1979 near Morgantown, W. VA. to elicit public comment on the planned location of a DOE sponsored coal liquefaction demonstration plan in the area. At the meeting, a representative from the Pennsylvania state government objected to the facility's location on the basis of migratory air pollution which would be carried into Pennsylvania by prevailing wind patterns.

- Representatives from the Commonwealth of Kentucky have threatened legal action to block an Indiana decision granting a license to an Indiana Public Service Co. nuclear plant which would be located on the Ohio river less than 50 miles upstream from Louisville.

- The New York Harbor Interstate Sanitation Commission, an interstate compact established in 1955; is representing the State of New Jersey in a lengthy public hearing concerning the location of a new Consolidated Edison Co. generating plant on Staten Island. Although the hearing is being conducted by the New York Public Service Commission, which will retain final decision-making authority, testimony on the plant's impact on the neighboring New Jersey environment is being considered. 
As the third example shows, interstate compacts may provide a means for decisions related to energy facility planning, siting and permitting to be made on a regional, interstate basis. This paper will explore the capabilities and limitations of interstate compacts in this regard.

\section{Framework for Analys is}

At the outset, it should be noted that existing compacts have had no significant involvement in or effect on energy facility siting decisions. When interviewed, some agency representatives expressed interest in the idea of siting issues and one, the Ohio River Valley Water Sanitation Commission (ORSANCO), is considering studying the feasibility of expanding its mandate to cover this function. Direct experience in dealing with this issue, however, does not exist,

Thus, comparisons between siting decisions that were made with a compact and those that were not is not possible. The assessment therefore must be made indirectly by extrapolating from the experiences of existing compacts. This assessment requires a framework for analsysis as outlined in the following paragraphs.

The functions basic to energy facility siting have, in a general sense, their counterparts in many existing compacts. These functions are 1 isted in terms of how they. would apply to energy facilities.

- Monitoring and Research: Siting decisions often require technical analysis which must be supported by basic research. The most common type is environmental research. This includes gathering data on air and water quality, drainage and wind patterns, plant and animal life and other environmental variables. Other research is conducted to develop and evaluate new pollution control technologies and monitoring devices. Although siting permit applicants have generally been responsible for gathering data to support their application, some states (e.g., California, Michigan) are beginning to conduct more research and site-selection activities themselves. 
- Resource Planning: Resource planning, which includes land-use planning, urban planning and water rights allocation, is an intermediate step between basic research and permitting. State planning agencies use data on natural resources and ecosystems to make decisions on the suitability of land areas for various types of development or the allocation of a scarce resource (e.g., water in the Colorado $R$ iver basin). Land-use planning and zoning are also carried out at the local level.

- Standard-Setting: The most substantive regulatory activity carried out by most state environmental agencies is the adoption of legislation and regulations establishing pollution control standards for facilities located within the state. These standards may constitute state implementation of a program mandated by Federal legislation (such as State Implementation Plans established under \$llo of the Clean. Air Act) or may result from state initiatives. Applicants for facility siting permits must demonstrate that the facility will comply with applicable state environmental standards.

- Permitting: Reviewing applications and granting permits is an essential element of any facility siting program. Most programs require applicants to submit detailed descriptions of their proposed facility and its environmental impacts. These applications are reviewed internally by the state permitting agency and may be forwarded to other government agencies, private groups and individual citizens for comment. In addition to the authority to simply grant or deny a permit, most agencies can also attach certain conditions to the award of a permit, such as the requirement that specific control equipment be installed or that effluent discharges be located at specific points.

- Enforcement: Enforcement generally consists of two activites, compliance monitoring and assessing penalties. Compliance monitoring can include reviewing reports submitted by facility operators, conducting on-site 
inspections, and operating sophisticated sampling and monitoring equipment. Assessment of penalties, such as show-cause orders, violation notices or fines, may be carried out by a separate legal agency of the state government. Enforcement is more applicable to operating permits (e.g., air, water or solid waste disposal permits) than to siting permits.

These functions receive different emphas is in different states. They may all be carried out by one state agency, or delegated to several offices within the state government. Some of these activities (particularly basic research and standard-setting) may be supported by funds or guidance from the federal government. To some extent, the above types of functions are addressed by current compacts, though they are carried out for other purposes than energy facility siting per se. Consequently, how successfully and how extensively existing compacts currently handle such functions can provide at least an inferential framework for assessing the concept's prospects in dealing with siting questions. Finally, this study not only looks at existing compacts in terms of these functions, but also in terms of what kinds of organizational structure they have and what conditions seem critical to their effectiveness in meeting their stated objectives.

\section{Organization}

Section II of tris paper defines the basic concept of an interstate compact. Section III presents a survey of interstate compacts existing today in the U.S., with brief descriptions of the compacts examined during this study. Section IV contains longer case studies of three compacts which were examined in detail. Section $V$ discusses criteria for the establishment and operation of effective compacts in general, and explores the potential benefits offered by interstate compacts for conducting energy facility siting. Section VI concludes the paper by discussing the extent to which the Federal government could play a role in establishing and supporting interstate compacts to address energy facility issues. 


\section{BASIC CONCEPT OF AN INTERSTATE COMPACT}

\section{A. Purpose}

A need to regulate the use of the limited resources in multi-state regions may arise when an increase in industry within the region potentially threatens. the quality and/or availability of the resources. Because these effects are not confined within state boundaries, the issues surrounding them cannot always be resolved successfully by the individual states acting in isolation. Compacts create a potential mechanism for states to join together in dealing with interstate issues to the satisfaction of the affected states.

\section{B. Constitutional Guidelines}

The U.S. constitution forbids states from entering into agreements or compacts without the consent of the Congress, when such agreements tend to increase the political power of the states relative to the Federal government. 1 / Any agreement that assigns decision-making authority, which is traditionally the province of one state, to a multi-state agency encroaches upon the authority of the Federal government. For example, an agency with the authority to enforce pollution control laws of one state against polluters in another would require Congressional approval.

When an interstate agreement does not interfere with the powers of the Federal government, Congressional approval is not necessary. Specific examples of this case are compacts which provide for:

- joint agency hearings;

- common agency decision-making schedules, and

- joint planning to mitigate environmental effects.

\footnotetext{
1/See U.S. Steel Corporation vS. Multi-state Tax Commission, 434 U.S. $45 \hat{6}, 471,(1978)$
} 
In cases where the necessity of Congressional approval is not clear, Congressional pre-approval may resolve the issue. $1 /$

C. Definition and Membership

An interstate compact is a formal, legal interstate agreement approved by the member states and, if necessary, by congress. The implementation of a compact's provisions frequently requires an organization, which this paper calls an interstate agency, to perform specific tasks.

Since a mutual interest in a common resource precedes most compacts, only states that share resources are likely candidates for compacts. Consequently, the number of members states in any given agreement is 1 imited (e.g.,. two to eight).

II For a further discussion of requirements for forming such compacts, see C. Schroeder, "Interstate Compacts to Address Multi-State Permitting and Regulatory Problems Associated with Synfuels Development," July 1979. 


\section{SURVEY OF EXISTING COMPACTS}

\section{A. Types and Purposes of Compacts Reviewed}

This section discusses two types of compacts and their purposes: resource usage compacts and resource quality compacts. The first type deals with resource allocation issues, while the second addresses resource standards. The older and more common type of compact is for resource usage. As with pollution control regulation in general, the growth of interstate resource quality compacts began only in the past 10-15 years.

\section{Usage Compacts}

Most existing compacts are 1 imited agreements on the allocation of a natural resource or the settling of a state boundary dispute. Some agreements have been implemented by interstate agencies; others are merely legal agreements, created or supported by Federal court decisions. Agreements allocating water rights among several states and economic sectors (e.g., agriculture, industry, residential) are common examples:

\section{a. Colorado River: Water Usage}

The Colorado River Compact (CRC), ratified in 1922, and compacts for five other rivers (Arkansas, Costilla Creek, Republican, Rio Grande, Platte) are typical.water usage compacts. These compacts were created to ensure "equitable division and apportionment of the use of the waters;... to promote interstate comity;... to remove causes of present and future controversies; to secure the expeditious agricultural and industrial development of the basin, the storage of water and to protect $1 \mathrm{ife}$ and property from floods. "I/ Water usage compacts are among the oldest interstate agreements. They have provided a model for the creation of recent interstate agreements, whose functions are more complex and diverse than these.

II Compacts on the colorado and above-mentioned rivers may be found in the 1973 Colorado Revised Statutes. CRS 1973 73-60 to 69-101, 37-69-103, 104. 


\section{b. Lake Tahoe: Land Usage}

The Tahoe Regional Planning Agency (TRPA), among its many activities, constructed a general plan for land use in the Tahoe Basin in the early 1970s. The plan for development was based on a categorization of the soils, and a definition of the tolerance of each soil type for development. The plan also predicted potential impacts on vegetation, and defined areas of sedimentation and erosion. This information was then used to support decisions relating to population density and zoning. TRPA will be discussed in more detail later in this section.

\section{c. New York and the District of Columbia: Land/Transit Usage}

Another type of compact is one that is very limited in scope. A commerce and transportation agreement, like the Port Authority of New York and New Jersey, is an example. A second type of transportation agreement exists among the states of Virginia, Maryland, and the District of Columbia for the Metropolitan Washington Transportation Authority.

\section{Quality Compacts}

Regional planning and environmental quality problems form the basis of: more complicated and broad-ranging agreements. Experience with multistate compacts handling multi-media probelms is extremely limited. Usually, planning and environmental quality compacts focus on one medium, often water.

a. Great Lakes: Water-Quality Recommendations

The Great Lakes Commision (GLC), is "dedicated to the wise use, development, conservation, and protection of the Great Lakes and its fresh 
water resources."II This commission is primarily empowered to:

- "collect, correlate, interpret, and report on data relating to water resources..."

- "recommend methods for the orderly, efficient, and balanced development, use, and conservation of the water resources..." 2 /

The results of the Commission's work are policy suggestions, such as flood plain and other zoning laws, or recommendations for uniform safe and efficient waste disposal from vessels. The GLC does not issue water pollution permits itself.

b. New England: Water Quality Administration

The New England Interstate Water Pollution Control Commission (NEIWPCC) is similar in purpose and focus to the GLC. Unlike the GLC, the NEIWPCC is more actively involved in the implementation of the states' water pollution control programs. In addition to setting quality standards for interstate waterways, this Commission has trained water treatment plant operators and provided staff to assist in processing industry grant applications. Once it acted as an EPA liaison for the states by meditating an interstate problem relating to the issuance of a permit for a treated effluent discharge. $\underline{3}$

\section{c. Tennessee River: Water Quality Authority}

The Tennessee River Basin Water Pollution Control Compact (TRBWPCC) created a commission with powers to "promote effective control and reduction of pollution in the waters of the Tennessee River Basin." 4/ TRBWPCC studies water

If "The Great Lakes Commission: What is it...what it does...how it works for you." Ann Arbor, Michigan (1975).

2/ For the compact in its entirery, refer to P.L. 90-419, enacted July 24, 1968.

3/ For more information on NEIWPCC, see "The New England Interstate Water Pollution Control Commission 30th Annual Report." Boston, Massachusetts (1977).

4/ "Tennessee River Bas in Water Pollution Control Compact, 1955" may be found in Documents on the Use and Control of the Waters of Interstate and International Streams: Compacts, Treaties, and Adjudication, ed. by T.R. Witmer, U.S. G.P.0., Washinaton (1968). 
pollution problems, writes reports on surveys conducted, and drafts legislation. This compact is innovative in that the commission also establishes physical, chemical, and bacteriological standards of water quality subject to compliance by public and private entities.

Should the commission discover a violation, it notifies the violator. It is then his duty to comply with the standard or face either an administrative hearing or court proceeding. The court will review the order and may impose a fine or issue an injunction. In this case, the interstate compact not only delegates research and recommendation responsibility to the commission, but also authority. for setting and enforcing environmental quality standards.

\section{d. Tahoe and New York: Air Quality}

Air quality and the interstate effects of migratory weather patterns are the most recent concerns of the Tahoe and New York agencies. As with water pollution, air pollution generated in one state can be experienced by another, thus making air quality a regional concern.

Landscape Architecture and Planning Professors at the University of California at Berkeley and the Executive Director of TRPA agree that future regional planning for the Tahoe Basin should address air quality. I/ The occasional occurrence of smog in Tahoe has increased interest in this issue. Air quality is viewed as one of several factors affecting the carrying capacity or population density tolerance of the region.

Since 1973, the New York Harbor Interstate Sanitation Commission has cooperated with New York, New Jersey, and Connecticut in coordinating a

IThis information was gathered in interviews with Professor T. Dickert and Executive Director J. Jordan, September 6-7, 1979. 
study of the interstate transport of photochemical air pollution. During 1978, it completed an analysis of ozone concentrations associated with a july 1977 heat wave. NHYISC has also been developing a regional air pollution warning system, as. well as conducting numerous studies of aerosols, particulates, and toxic airborne elements. This agency is addressing these air pollution issues in greater depth than other interstate agencies by analyzing air pollutants in the region.

\section{B. Common Traits of Compacts}

Exhibit. I below provides summary information on a 11 compacts discussed in the preceding section.

\section{EXHIBIT 1}

Summary of Interstate Compacts and Agencies

\begin{tabular}{|c|c|c|c|c|}
\hline FULL NAME & ACRONYA & YEAR FORNED' & MEMABER STATES $2 /$ & PIJRPOSE \\
\hline Colorado River Compact & CRC & 1922 & $\begin{array}{l}A Z, C A, C O, \text { NPI, NIV. } \\
\text { iiT, WY }\end{array}$ & Water Nllocation \\
\hline $\begin{array}{l}\text { New York Harbor Inter- } \\
\text { state Sanitation } \\
\text { Comanission }\end{array}$ & NYHISC & 1935 & $C T, N J, N Y$ & $\begin{array}{l}\text { Water follution } \\
\text { Control }\end{array}$ \\
\hline $\begin{array}{l}\text { Ohio River Valley Water } \\
\text { Sanitation Commission }\end{array}$ & ORSANCO & 1939 & $\begin{array}{l}I L, \underset{I N,}{I N Y, N Y, O H}, \\
P A,, U A, W N\end{array}$ & $\begin{array}{l}\text { Nater Pollution } \\
\text { Control }\end{array}$ \\
\hline $\begin{array}{l}\text { Newv England Interstate } \\
\text { Water Pollution Control } \\
\text { Conmission }\end{array}$ & NEIWPCC & 1947 & $\begin{array}{l}C T, M A, M E, M I I, N Y, \\
P I, V T\end{array}$ & $\begin{array}{l}\text { Water Pollution } \\
\text { Control }\end{array}$ \\
\hline Great Lakes Cormission & GLC & 1955 & $\begin{array}{l}I L, I N, M I, M N, N Y, \\
O H, P A, W I\end{array}$ & $\begin{array}{l}\text { Planning \& Infor- } \\
\text { mation Services }\end{array}$ \\
\hline $\begin{array}{l}\text { Tennessee River Basin } \\
\text { Water Pollution Control } \\
\text { Conmission }\end{array}$ & TRBWPCC & 1955 & $A L, G A, T N$ & $\begin{array}{l}\text { Water Pollution } \\
\text { Contral }\end{array}$ \\
\hline $\begin{array}{l}\text { Tahoe Regional Planning } \\
\text { Agency }\end{array}$ & TRPA & 1969 & $\mathrm{CA}, \stackrel{3 /}{\mathrm{NV}}$ & Land-use Planning \\
\hline
\end{tabular}

I/ Year the compact was first formed. Many of the conpacts have been revised over time and some clain different dates of origin.

2f State codes are the 2-letter postal codes.

3/ As of 1979, California has withdrawn support from TRPA. 
Interstate compacts are similar in the environmental issues and media which they address. Other similarities include decision-making procedures and the role of the Federal government.

\section{Membership and Organization}

The agency frequency includes two groups: a commission and a staff. The commission is the governing board of the organization and has final authority on all policy and substantive issues. The staff is the group of technical and administrative professionals who perform the substantive work of the commission.

The commission typically is composed of non-paid private citizens and state agency officials with final voting authority for the agency. The number of member states in a compact varies from two to eight, and a Federal representative may sit on the commission. Each state's group of representatives is a "delegation", and three to five representatives may be in each delegation. Each delegation consists of state and local representatives either appointed or ex officio. Since two to eight states and the Federal government may be represented, the commission could range from six to fortyfive members. The typical size is twenty-five commissioners.

These commissioners meet two to four times annually to set policy and decide major issues. The staff' usually performs the background and preliminary work for these meetings. The staff may also conduct analyses, perform surveys, prepare standards and make proposals to the commission.

The agency also may have an advisory planning group and several standing committees. The advisory planning group is like the commission in participation, but more like a public forum in membership and influence. Hence, the advisory planning group has no binding authority over the agency. The standing committees address specific agency concerns. Typical standing committees include the Executive, Engineering, Policy, Legislative, and Water Use committees. Unlike the advisory group, the standing committee members are also members of either the staff or the commission. 


\section{Funding}

The amount of funding in any fiscal year usually determines the staff's size and activities. Since the commissioners typically are state appointees who receive no compensation, funding rarely determines the size of the commission.

Individual states' financial contributions may vary by the percentage of the agency's jurisdiction which is within the state -- for example, the percentage of the drainage basin of a river that is included in the state. Another arrangement is for each member state to provide an equal contribution.

The type of primary responsibilities which an interstate agency carries out does not appear to influence the amount of the agency's funding. The New England Interstate Water Pollution Control Commission (NEIWPCC) classifies waters, sets quality standards, acts as a liaison to the EPA, and analyzes and drafts policy, among other tasks. The NEIWPCC has received as much as $\$ 700,000$ for $i$ ts activities from the member states, but typically receives between $\$ 300,000$ and $\$ 500,000$. In Tahoe, the Tahoe Regional Planning Agency (TRPA) has received an average of $\$ 600,000$ from the member states and their localities for drafting and enforcing ordinances, planning land usage, and reviewing and approving or disapproving new developments. Presently it receives about $\$ 250,000$ from only one state for the same responsibilities.

The Federal share of interstate agency budgets fluctuates more than the member states' share. Federal grants usually require the agency to prepare additional plans or undertake additional studies. Complying with such a condition may be difficult but can boost the agency's annual budget substantially. For example, the Ohio River Valley Water Sanitation Commission received $\$ 750,000$ from the Federal government in 1978 . 


\section{Decision-making Procedures}

Exhibit II on the following page shows the voting and decision-making rules for each compact surveyed. In most cases, a simple majority vote from each state delegation is required for the action of the commission to be binding. Athough this procedure protects the autonomy of each state, it can hinder the resolution of a dispute between two or more states. Unless there is a contingency plan for resolving such deadlocks, the effectiveness of the agency can be substantially reduced. The dual majority voting system used in the TRPA, which requires a majority of both state delegations to disapprove a proposed project, is. a good example of this.

\section{Role of the Federal Government}

The effect of the Federal government on interstate agencies is threefold:

- Initial Congressional approval of the compact;

- Award of Federal grants (usually requiring additional staff work); and

- Advice and support of ongoing agency operations from Federal officials.

Exhibit III describes the types of support granted to particular compacts by the Federal government. 


\section{EXHIBIT II}

Compact Decision-Making Rules

\begin{tabular}{|c|c|}
\hline COMPACT & RULES \\
\hline Colorado River Compact & - Not available \\
\hline Great Lakes Compact & $\begin{array}{l}\text { - Each. state delegation shall be entitled to } \\
\text { three votes in the commission. } \\
\text { - The presence of commissioners from a majori- } \\
\text { ty of the party states shall constitute a } \\
\text { quorm } \\
\text { - A majority of the votes cast from each of a } \\
\text { majority of the states present and voting } \\
\text { is required to pass any resolution }\end{array}$ \\
\hline $\begin{array}{l}\text { Ohio River Valley Water } \\
\text { Sanitation Commission }\end{array}$ & $\begin{array}{l}\text { - One or more commissioners (or their proxies) } \\
\text { from a majority of signatory states consti- } \\
\text { tute a quorum } \\
\text { - The affirmative vote of a majority of com- } \\
\text { missioners present at a meeting is necessary } \\
\text { for adopting a motion. }\end{array}$ \\
\hline $\begin{array}{l}\text { New England Interstate } \\
\text { Water Pollution Control } \\
\text { Commission }\end{array}$ & $\begin{array}{l}\text { - For approval of water classification proposals, } \\
\text { a majority vote must be received from the mem- } \\
\text { bers of proposing states, the affected state } \\
\text { and the entire commission. } \\
\text { - Routine issues require a majority of the } \\
\text { entire commission. }\end{array}$ \\
\hline $\begin{array}{l}\text { New York Harbor Inter- } \\
\text { state Sanitation Commission }\end{array}$ & $\begin{array}{l}\text { - No action of the commission is binding unless } \\
\text { at least } 3 \text { members from each state (a majori- } \\
\text { ty) vote in favor thereof. }\end{array}$ \\
\hline $\begin{array}{l}\text { Tennessee River Basin } \\
\text { Water Pollution Control } \\
\text { Commission }\end{array}$ & $\begin{array}{l}\text { - Each commission has one vote, and a majority } \\
\text { vote of the members of each state is required } \\
\text { for a binding decision of the commission. } \\
\text { - Seven or more members from a majority of the } \\
\text { states constitutes a quorum. }\end{array}$ \\
\hline $\begin{array}{l}\text { Tahoe Regional Planning } \\
\text { Agency }\end{array}$ & $\begin{array}{l}\text { - Only by a majority vote of each state delega- } \\
\text { tion can the governing board take action. } \\
\text { - If no action is taken within } 60 \text { days by the } \\
\text { TRPA to prohibit a development project, it } \\
\text { is considered approved. }\end{array}$ \\
\hline
\end{tabular}


EXHIBIT III.

Role of Federal Government

\begin{tabular}{|lccc|}
\hline COMPACTS & APPROVAL & FUNDING & SUPPORT (ONGOING) \\
\hline CRC & Yes & No & N/A $1 /$ \\
GLC & Yes & No & Yes \\
ORSANCO & Yes & Yes & Yes \\
NEINPCC & Yes & Yes & No \\
NYHISC & Yes & Yes & No \\
TRBWPCC & Yes & N/A & No \\
TRPA & Yes & No longer - I & No \\
& & & \\
III Information not available. & & \\
2/ Formerly received EPA, DOT, and HUD funds. &
\end{tabular}

C. Functions Performed by Interstate Compacts

As noted in Chapter I, there are no existing compacts which have been established for the explicit purpose of facilitating energy facility siting. However, many compacts have established interstate agencies which carry out some of the five elements of facility siting programs. Exhibit IV on the following page describes the extent to which each of the seven compacts referred to in this study is involved in each of the five major siting program activities.

The sections which follow discuss each activity individually to provide a summary assessment of which facility siting functions are currently performed by interstate agencies. 


\section{EXHIBIT IV}

Functions Performed by Existing Interstate Agencies

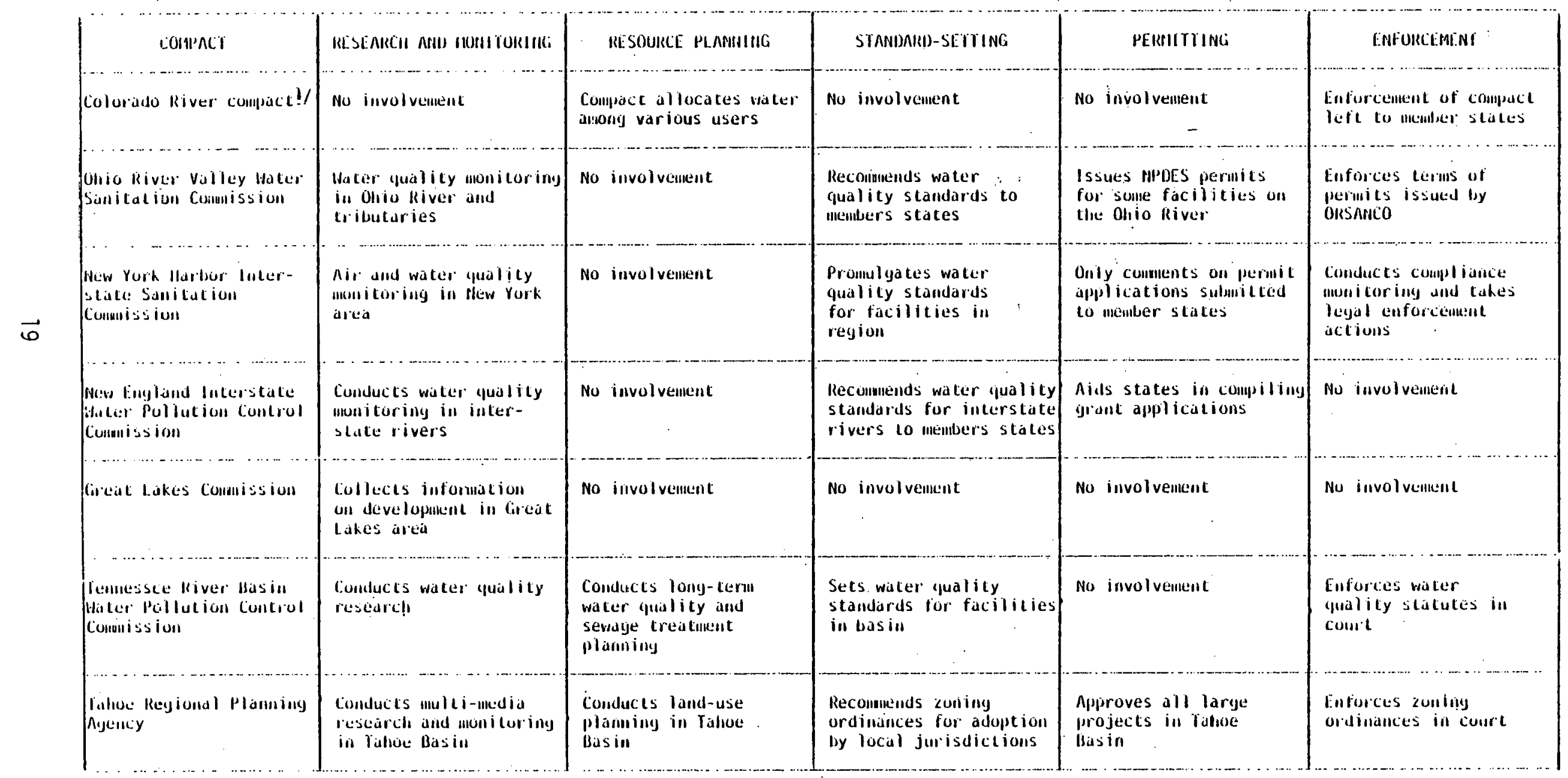

$1 /$ No interstate agency is actually created by this compact. The member states implement the agreement theinselves. 


\section{Monitoring and Research}

Most interstate agencies conduct some form of monitoring and research. One of the most common types is monitoring the pollution levels in bodies of water or other media covered by the agency's mandate. In some cases, interstate agencies have been able to secure sufficient funds from member states and the Federal government to undertake largesscale research projects which probably would not have been conducted by the individual member states. The Early Warning Organics Detection System developed by ORSANCO to detect concentrations of toxic pollutants in the Ohio River, and the extensive natural systems data base compiled by the TRPA in cooperation with the U.S. Forest Service to help categorize soils in the Tahoe Basin are two examples of such projects. Many of the monitoring and research activities conducted by interstate agencies are used to support resource planning or rulemaking activities by the agency or by' the member states. Federal agencies provide partial support for much of this work.

\section{Resource Planning}

The planning for or allocation of natural resources is the principal purpose of some interstate compacts (e.g., TRPA, CRC). However, not all interstate agencies perform.this function. The agencies which are most effective at resource planning are those that have been granted the authority to implement and enforce their plans, as opposed to those that can only make recommendations to member state governments.

\section{Standard-Setting}

Promulgating standards is one of the principal responsibilities which states are most reluctant to delegate to an interstate agency. The zoning ordinances established by TRPA and the water quality standards set by the NYHISC are exceptions, in that their mandates are unusually strong for this function. 
Although these two agencies have been effective in promulgating and enforcing standards, their applicability has been limited to a special and relatively small geographic region. The ORSANCO case, where the interstate agency can only recommend that members states adopt consistent water quality criteria, is more typical.

\section{Permitting}

In general, interstate agencies lack both the mandate and the resources to assume responsibility for issuing permits or expediting the permitting process conducted by member states. While many states accept support from interstate agencies for environmental monitoring and research, or consider their recommendations on a case-by-case basis, few states have been willing to include permitting authority in a compact. ORSANCO, which has the authority to issue National Pollutant Discharge Elimination System (NPDES) permits for a limited number of facilities on the Ohio River itse'f $f$, is an exception.'

\section{Enforcement}

It is more common for interstate Agencies to conduct compliance monitoring (often as part of a broader environmental quality monitoring program) than to take direct enforcement actions such as assessing fines or issuing shutdown orders. However, many interstate agencies become involved in compliance-related lawsuits with developers, utilities, and local governments. Although interstate agencies have generally been very successful in having enforcement actions upheld in court, there is little cooperation in legal proceedings between them and member states, and in some cases (e.g., TRPA) states have filed suit against an interstate agency which they are supporting. 
In general, states are more willing to delegate authority to interstate agencies to conduct background research and monitoring activities than to delegate substantive authority for the either rulemaking or permitting of individual facilities. Interstate agencies have generally been effective in conducting research and monitoring. The limited data available on the application of compacts to other activities indicate than interstate agencies can conduct effective, ongoing programs for standard-setting and permitting (particularly. the facilitating of the permitting process), if they are given the necessary authority and resources. 


\section{CASE STUDIES OF THREE COMPACTS}

This chapter reviews three interstate agencies in detail: (1) the Ohio River Valley Water Sanitation Commission; (2) the Tahoe Regional Planning Agency; and (3) the Interstate Sanitation Commission. Each of these agencies has:

- been granted the authority. to exercise control over at least some environmental issues;

- addressed at least one media-quality issue (usually water) on a regional basis; .

- worked directly with a liaison from or an agency of the Federal government in its day-to-day operations; and

- - acknowledged the need for a multi-state process for resolving natural resource issues of a regional nature.

A. The Ohio River Valley Water Sanitation Commission (ORSANCO)

ORSANCO embraces all the territory of the Ohio River Valley Basin, excluding the territory of the Tennessee River Valley Basin. The member states are Illinois, Indiana, Kentucky, New York, Ohio, Pennsylvania, Virginia, and West Virginia.

1. Purpose and History

The member states founded ORSANCO with the approval of the Federal government in 1939 to control future water pollution and abate existing water pollution in the Ohio River system. The member states believed that they could resolve pollution issues in the Ohio River Valley Basin only through joint cooperation and action. The success of ORSANCO in maintaining interstate cooperation rests on the principle that industrial waste from a signatory state shall not injuriously affect the uses of interstate waters. 
In the agency's early years, it performed considerable public relations work to emphasize the need for industrial and municipal sewage treatment facilities. It helped pass bond issues, performed technical research, and gathered data on the river through its "water users committee."

ORSANCO has the authority to address any regional issue related to water pollution, and has the potential to be a forum for resolving a variety of disputes.

\section{Organization}

ORSANCO is composed of a 27-member. Commission, whose members serve with- out compensation, and a full-time technical staff. The Governor of each member state appoints three members to the Commission. One of the three members is from the state's Environmental Control Agency. In addition, the U.S. President appoints three Federal Commissioners. The Commission's major responsibility is to establish ORSANCO's policy, and review the staff's effectiveness in implementing it.

The technical staff performs all the substantive work of the Commission. Staff members carry out the monitoring and enforcement activities, perform the technical and laboratory research and, in general, carry out the policies of the Commission.

\section{Funding and the Federal Government's Role}

The agency had a budget of $\$ 1,234,000$ in FY78. EPA awarded ORSANCO $\$ 404,000$ under Section 106 of the Federal Water Pollution Control Act and $\$ 248,000$ under the Safe Drinking Water Act. The agency received $\$ 375,000$ from the eight states. The states allocated the funding among themselves on a proportional basis -- 50\% based on population in the region and $50 \%$ based on land area in the region. A final $\$ 207,000$ came from various contracts, grants, etc., from the member states, the U.S. Army Corps of Engineers, and local water utilities. 
Federal funding often requires that an organization perform activities outside its routine functions. In the Ohio River case, Federal funding has enhanced ORSANCO's activities, and the attached "strings" have not sidetracked it from fulfilling its legislated mandate. Funds from the EPA and the Army Corps of Engineers have enabled ORSANCO to address water pollution concerns germane to the river system. Should Federal grants become available to address the issue of siting energy facilities in the Ohio River Valley Basin, it's likely that ORSANCO will pursue those which it is qualified to address.

\section{Current Activities}

The Commission meets three times per year and makes all its basic operating and policy decisions at the meetings. The major activities of the agency during the last few years were the following:

\section{a. Monitoring and Research}

- detecting spills on the river through its Early Warning Organics. Detection System, and disseminating appropriate warning and abatement information;

- measuring organic materials on a daily basis; and

- conducting technical research into water quality issues of concern to the Commission, such as yearly fish contamination studies.

b. Standard-Setting

- encouraging the states to adopt standard water quality criteria for the river, and

- encouraging cooperative efforts to comply with Federal legislation. 


\section{c. Permitting}

ORSANCO has the authority to grant permits under the EPA's National Pollutant Discharge Elimination System (NPDES) for some facilities located on the Ohio River.

ORSANCO's most recent action concerning energy facilities has been the creation of a Special Committee on the Siting of Major Energy-Related Facilities. The purpose of this committee is to explore methods through which ORSANCO can involve itself in the siting and permitting of large energy facilities. Since the agency is not a zoning authority, its most likely contribution will be in the form of environmental evaluations of water and solid waste considerations.

\section{d. Enforcement}

ORSANCO enforces the terms of its own bylaws and the NPDES permits which it issues. Enforcement action can be taken only after approval by a majority vote of the commissioners from the offending state and majority vote of the entire Commission.

\section{Effectiveness}

During the past 30 years, ORSANCO has contributed to the control and abatement of water pollution in the Ohio River Valley Basin as measured by the following criteria:

- Tripling of the Ohio River fish population during the past 20 years;

- Increase in recreational uses of the river;

- Disappearance of $0 i l$ slicks and man-made debris; and

- Increased compliance with ORSANCO's criteria for the presence of dissolved oxygen, acid, and organic compounds. 


\section{Conclusions}

Several conclusions relevant to compacts and their potential role in regional planning and permit-granting for large energy facilities can be drawn from ORSANCO's experiences:

- The commissioners' competing commitments and their physical distance from the staff have hindered them from becoming actively involved in ORSANCO's activities, with the result that the senior staff runs the agency.

- The large percentage of Federal funding and the difficulty in obtaining increased support from the member states makes ORSANCO responsive to the policies of the Federal government. Although this has not caused problems to date, conflict and decreased funding could result. if Federal and regional priorities were no longer consistent.

- Federal membership on the Commission has some advantages for ORSANCO. Active participation by the Federal delegation has provided ORSANCO with information concerning other similar problems and Federal funding opportunities.

- The Commission's interpretation of its legislative mandate implies that ORSANCO will not license or grant permits for energy facilities, and may be reluctant to address media other than water. Changes in its enabling legislation would be required to encourage a more active role in this area.

- Should ORSANCO choose to pursue the issue of energy facility siting, it would do so from an environmental or economic perspective, rather than simply conducting energy supply planning. 
B. The Tahoe Regional Planning Agency (TRPA)

Lake Tahoe straddles the California-Nevadaborder in a granite and volcanic basin surrounded by snow-topped mountain peaks. The lake is not only the largest and deepest lake in the Sierra Nevada but one of the largest alpine lakes in the world. It is also noted for its color and clarity.

\section{Purpose and History}

Tahoe has attracted millions of visitors during the past twenty-five years, for both outdoor recreation and gambling. Seventy-nine percent of the visitors are from California, and 14\% from Nevada. A1l other states and countries account for the other $7 \%$. The rate of increase in both visitors and permanent residents has been dramatic in the past twenty-five years. Until the establishment of TRPA, the Basin was developed rapidly without considering the environmental consequences and adverse effects on Lake Tahoe. I/

The U.S. Forest Service has acquired $64 \%$ of the 1 and around the lake in the past forty years, al though efforts to establish state parks have failed there. In 1969, the Tahoe Regional Planning Agency (TRPA) was established as a result of a Bi-State Compact between California and Nevada. The compact recognized that the region was experiencing problems of resource use and lack of environmental control. The mandate of the compact was "to establish an area-wide planning agency with power to adopt and enforce a regional plan of resource conservation and orderly development. "ㄴ?

\footnotetext{
II "Background Information," Federal Policy for the Lake Tahoe Basin, Western Federal Regional Council, August 1978.

2/ "TRPA Compact," Tahoe Regional Planning Agency: An Overview, September 1975, and P.L. 91-148, December 1969.
} 
TRPA's mission was to develop and maintain a regional plan for the entire Basin. The intent of that plan was to maintain an equilibrium between the region's natural resources and its man-made development and to preserve the scenic beauty and recreational opportunities of the region. The mandate also empowered TRPA to implement and enforce all the ordinances and regulations deemed necessary to execute the plan. II

\section{Organization}

TRPA has three levels of authority: the Governing Board, the Advisory Planning Council (APC), and the staff. In July of 1979, the California delegation withdrew from the agency due to the agency's perceived inability to halt the proliferation of casinos and condominiums. At present, the Governing Board, which is the ultimate decision-making authority, is seven in number. It is composed of three local government representatives., one Governor's appointee, the natural resources agency director for each state, and a non-voting Presidential appointee. The size of both the APC and the staff is currently about the same as that of the Governing Board.

As with ORSANCO, TRPA has been positively influenced by the inclusion of its Federal representative, who is the Regional Director of the U.S. Forest Service. This representative has provided guidance and constructive comments in TRPA discussions, as well as technical support for the development of the land capability thresholds. $\frac{\text { I }}{}$

II "Background Information," Federal Policy for the Lake Tahoe Basin, Western Federal Regional Council, August 1978.

2/ Land capability thresholds are the ground coverage and population levels that the area can support without straining existing services (e.g., sewage) or utilities (e.g., power). 


\section{Funding and the Federal Role}

Federal funding has had a mixed effect on TRPA's activities. EPA money (from Section 208 of the Federal Water Pollution Control Act) enabled TRPA to pursue the development of a water quality plan. EPA also offered its technical assistance. EPA required, however, that TRPA develop a data management system, which severely strained agency resources. HUD provided funding under its $\$ 701$ program on the condition that TRPA develop a-low-to-moderate income housing plan. Although DOT offered money, the two states could not agree on the design of a transportation plan.

The reduction in the TRPA staff has greatly affected the capacity of the agency to comply with these Federal requirements. Since the withdrawal of the California delegation, overall state funding has been substantially reduced (by about $60 \%$ since 1975). The result is that, al though TRPA desperately needs Federal funding to perform the minimum responsibilities under the mandate, it has neither the personnel nor the capability to comply with the conditions of Federal grant programs. Should Federal money such as low-interest loans or block grants become available to pursue the environmental concerns of the Basin, TRPA might take advantage of them. Since energy facility siting is not an issue in the Tahoe Basin, it is unlikely that TRPA would be attracted to funding for that issue. Currently, TRPA receives no Federal funding, and is entirely dependent on the six local jurisdictions in the Basin and the State of Nevada.

\section{Current Activities}

TRPA is currently engaged in four types of activities:

\section{a. Monitoring and Research}

The agency's staff, working with researchers from the University of California, compiled a large data base containing multi-media information on the Basin's natural resources (e.g., climatology, hydrology, geology). 


\section{b. Resource Planning}

The natural systems data base was used to establish a "land capability" planning system. In this process, all land in the Basin was classified into one of seven soil categories. TRPA then set limits on the allowable percentage of ground coverage for new projects, depending on the soil category of the proposed project site. TRPA has developed numerous other plans (e.g., Land Use, Conservation, Recreation, Public Facilities, and Transportation) for the area and has passed ordinances to enforce those plans.

\section{c. Permitting}

A11 local jurisdictions have passed ordinances which require TRPA approval of any commercial project larger than three acres, and any residential structure containing more than five units. The agency staff reviews all such proposed public and private projects and recommends approval or disapproval to the Governing Board, which addresses the proposals in its monthly meetings.

\section{d. Enforcement}

The legal activities include the drafting of ordinances and their enforcement. Most recently, the legal function has been expanded to include defending the agency against lawsuits brought by developers, environmentalists, and the State of California. The suits have focused on the constitutionality of the agency and its ordinances, the dual majority rule, agency review authority, and prior condemnation of land to preclude commercial development.

The FY80 activities of TRPA will focus on continuing the carrying capacity analysis, reviewing proposed developments, and legal defense. The agency is awaiting the 1981 reconvening of the Nevada state legislature, which will address the badly needed revisions proposed in the Bi-State compact. California and Nevada are expected to reconcile their differences related to defining the long-range goals of the Tahoe Basin, as well as cooperate in reconstructing the agency's powers to implement these goals. 


\section{Productivity and Effectiveness}

In general, TRPA has been ineffective in managing growth in the Tahoe Basin, although the TRPA staff has been innovative and somewhat successful in their analyses and planning. To some extent, this failure is due to the fundamental conflict existing since the beginning of the compact, between state priorities for natural preservation and commercial development. This conflict has been difficult to resolve because the compact does not give TRPA the authority to force compromises. In addition to the state vs. state conflict, other problems have undermined the agency's effectiveness:

Local vs. State Conflicts: The majority of the Governing Board is made up of local representatives, who generally favor increased commercial development in the Basin. This has increased the disenchantment of California state-level policymakers with TRPA.

- Internal Agency Conflicts: The Governing Board has often overruled the planning staff when the staff has recommended disapproval of projects that would violate land capability or density restrictions. This has weakened the credibility of the agency.

- Inadequate Legislative Coordination: Although TRPA was set up to function independently of the two state legislatures, they must approve any revision to the compact. Recent efforts to revise the compact have been hindered by the infrequency with which the Mevada state legislature meets (only once every two years).

- Lack of Flexibility: It has been suggested that TRPA suffers from a lack of flexibility in its mandate. While the agency is is forced to consider multi-media effects in making planning 
decisions, its scope of authority is constrained to the fivecounty. Bas in area. This presents difficulties when migratory air pollution and population shifts must be considered.

- Realistic Funding Base: As was demonstrated by the withdrawal of the California delegation, funding arrangements can drastically effect the viability of an interstate agency. It has been suggested that Federal grants could stabilize potential fluctuations in the budget that result from these and other disputes:(e.g., legal suits).

\section{Conclusions}

TRPA does not anticipate addressing energy issues per se, al though the environmental quality considerations that relate to energy could be of interest to the agency. An unavoidable future planning issue is expected to be the capacity for and routing of traffic. The topography of the Basin lends itself to . temperature inversions that result in $\mathrm{NO}_{x}$ and sulfur levels close to those of Los Angeles.

The land capability system developed by. TRPA could potentially be expanded to arrive at air and water quality thresholds, and perhaps carrying capabilities for energy facilities. TRPA has already been innovative in developing multiple land use plans, as well as enforcing ordinances which implement the plans. This explains much, of the controversy TRPA has faced. TRPA's "bottom-up" planning approach, with regional planners pre-determining sites and development guidelines which minimize environmental damage to the locality, corresponds to current trends in state and local regulation of energy facility siting. 


\section{Interstate Sanitation Commission}

The Interstate Sanitation Commission enforces water quality standards in the greater New York City Harbor area. This region includes all of New York City Harbor and all the waters surrounding Manhattan and Staten Islands. It extends to New Haven and Fort Jefferson on Long Island Sound, to Raritan Bay and Sandy Hook Bay in New Jersey, to Fire Island Inlet on the South coast of Long Island, and to the northern line of Westchester County on the Hudson River.

\section{Purpose and History}

The Interstate Sanitation Commission was established in 1935 through the enactiment of the New York (Tri-State) Interstate Sanitation Compact. New York and New Jersey were the original members; Connecticut joined in 1942.

The Commission's original purpose was to control future pollution and to provide for the abatement of existing pollution in the tidal and coastal waters of the greater New York City Harbor area. This mandate has been expanded to include monitoring air pollution in the same tri-state area.

During the Commission's, early years, its major activity was convincing local communities of the need for municipal sewage treatment plants. The commission classified the waters in its district, established water quality standards for the classes of waters, encouraged the member states to enact consistent legislation incorporating these standards, and enforced its own standards through administrative and court action. Until the early 1960's, the Commission was the sole enforcer of water quality standards in the harbor area.

\section{Organization}

Five commissioners, who serve without compensation, represent each state. One member from each state is the head of that state's Department of Environmental Protection. In addition, Connecticut's and New Jersey's commissioners of Public Health are also ex officio members of the Commission. 
The other members are appointed by the Governors and confirmed by the Senators of the respective states. No. Federal representatives serve on the Commission.

The Commission holds quarterly meetings to act upon major policy. issues. The Chairman and two Vice Chairmen occasionally hold special meetings to deal with pressing issues arising between the quarterly meetings. A full-time staff of approximately 25 people performs the substantive and technical work of the Commission. They implement the policies of the Commission, conduct all technical work, and bring major policy issues to the Commission for consideration.

\section{Funding and the Federal Government's Role}

The Commission has an annual buidget of approximately $\$ 800,000$. The Environmental Protection Agency (EPA) provides about $40 \%$ of their funds under Section 106 of the Federal Water Pollution Control Act. The member states provide the remaining funds. Of this amount, New Jersey and New York each provide $45 \%$ and Connecticut provides $10 \%$. The Commission spends $70 \%$ of its budget on water pollution control activities and 30\% on air pollution monitoring activities.

Despite heavy Federal funding and the constant interaction between the staff and the EPA, the federal government is not involved in setting the Commission's policy or managing the operations of the staff. The EPA grant provides general operating and administrative funds and has few, if any, conditions attached.

\section{Current Activities}

The NYHISC is active in three areas related to facility siting:

\section{a! Monitoring and Research}


- Monitoring water and air quality by operating continuous. monitoring stations and analyzing periodically collected samples;

- Performing laboratory work and technical reserach for EPA, member states, and the U.S. Army Corps of Engineers; and

- Conducting special studies and sampling programs to analyze the causes and effects of both air and water pollution.

\section{b. Permitting}

Although the NYHISC conducts no direct permitting activities on its own, it does represent other commission states in state hearings on the licensing of new power plants and other large facilities with regional environmental impacts.

\section{c. Enforcement}

The member states normally perform all enforcement activities with the technical assistance of the staff. However, the staff usually handles all politically sensitive issues because it is more removed from political influence than state agencies. Furthermore, the Commission can enter Federal court to enforce its regulations if the state fails in its own courts. The two major areas of enforcement action conducted by the NYHISC are the following:

- Inspecting municipal sewage treatment facilities to ensure compliance with NPDES discharge permits; and

- Cooperating with Federal, state and local agencies to enforce compliance with all appropriate water and air quality standards in the tri-state district. 


\section{Effectiveness}

The Commission and its staff are fulfilling their mandate by:

- Helping the member states adopt and enforce consistent water quality. standards;

- Participating in the planning for and construction of 99 municipal treatment facilities;

- Establishing water and air monitoring programs to track pollution and effluent levels;

- Establishing and enforcing water quality standards more stringent than those of the EPA or the member states; and

- Maintaining a technical staff capable of providing the technical research and support for its monitoring, abatement, and enforcement activities.

6. Conclusions

Several conclusions applicable to the potential effectiveness of an interstate compact for energy facility planning can be drawn from the experiences of the Interstate Sanitation Commission:

- A limited mandate (water poliution abatement) helped focus the Commission's role in the early years. The staff was able to direct all its efforts toward this objective, and thus accomplish specific goals.

- Providing the Commission with enforcement powers enabled it to deal successfully with corporate and municipal violators of its regulations. 
- Maintaining a capable technical staff enabled the Commission to pursue administrative and adjudicative relief, confident that its conclusions and recommendations were technically sound.

- Encouraging cooperation among the staffs of the Commission and Federal, state, and local agencies provided a framework for the exchange of information and ideas. It also enabled the implementation of a more comprehensive effort to monitor water quality and enforce the water quality standards and abatement procedures. 


\section{POTENTIAL UTILITY OF COMPACTS FOR FACILITY SITING}

The preceding two chapters provided a general overview of existing compacts, as well as a more in-depth discussion of three compacts dealing with resource quality and usage issues. Based on these investigations, this chapter offers summary conclusions regarding what seem to be the general prerequisites for a successful compact, and examines the potential applicability of the compact concept to resolving energy-facility siting issues.

\section{A. Basic Conditions for Effective Compacts}

The experiences of existing compacts argue that the following five inder! lying conditions appear necessary for any interstate agency to deal effectively with regional issues, particularly the type of issues likely to be associated with the siting problem.

\section{Reasonably Consistent Goals and Policies}

States entering into an interstate compact should share reasonably consistent priorities and goals with respect to economic and energy development and environmental protection. As illustrated in the Lake Tahoe experience, the geographic proximity of states is not a sufficient basis for conducting regional environmental planning, and states with economic and environmental priorities as disparate as those of California and Nevada would likely have little success in trying to carry out planning for energy facilities. On the other hand, states such as the ORSANCO member states, which begin with somewhat consistent policies, would have more potential for resolving disputes and making progress.

\section{Clear and Strong Mandate}

Interstate compacts and the agencies which they create require a clear mandate to guide their operations. The most effective existing compacts (e.g., New York Harbor, ORSANCO) are those which concentrate their resources on addressing relatively specific and well-defined issues, however limited. 
The strength of the mandate is also a factor in a compact's effectiveness. Interstate agencies which can only conduct studies and make recommendations (e.g., Councils of Governments, Governors' Conferences) obviously have less problem-solving potential. Agencies which are granted the authority to implement and enforce. their own policies and regulations can conduct more effective planning, and will likely be better able to resolve interstate disputes.

\section{Independent Organizational Structure}

Interstate agencies need to: be managed by full-time agency staff, rather than by state employees who have only a marginal or part-time affiliation with the agency. The agency is likely to be more effective if it maintains a close working relationship with the compact states, interacts with the legislative and executive branches, and prepares a yearly report describing the agency's activities and outlining its plans for the coming year, accompanied by budget requirements to carry them out.

\section{Technical Staff Expertise}

Given the need for an interstate agency to conduct substantive research and planning and to resolve disputes, it must be technically credible. It is critical that agencies be able to attract and maintain competent technical staffs.

A full-time technical staff is generaliy required, since the commissioners are not in a position to perform the research and analys is function effectively. Most commissioners have other permanent positions within their state governments and serve the interstate agency without pay, which leaves limited time for agency work. Consequently, they cannot keep abreast of interstate issues at a detailed level, nor perform required analyses. Moreover, since a commissioner's first allegiance is to his state, rather than to the region, it is more difficult to achieve objectivity. A full-time staff, paid out of general agency funds, is more likely to take an objective, regional perspective. 


\section{Adequate and Flexible Funding}

One of the major factors limiting the effectiveness of interstate compacts is the instability of their financial resources.: Compacts are often funded by each member state agreeing to contribute a given sum each year to support an interstate agency. This amount is agreed upon when the compact is approved, and cannot easily be raised to respond to inflation and the agency's increasing workload. Consequently, agencies must seek additional revenue from other sources. Identifying and tapping new sources of funding is a formidable task, which may divert the focus of the agency.

Flexibility in the funding mechanism is helpful in this regard. A possible approach is to specify only a base level of state financial support in the compact, providing the agency with more of a capability to expand (or reduce) its scope and level of effort over time, while ensuring that it remains responsive to the goals and priorities of the member states.

\section{B. Potential Benefits of Compacts for Facility Siting Programs}

This section provides an assessment of the potential contribution of interstate compacts to each element of facility siting programs. The discussion assumes that states are, in fact, willing to delegate the authority for these functions to interstate agencies.

\section{Basic Research}

Compacts can be used to expand the scope of basic environmental and technical research conducted by individual states. In cases where rivers or harbors border on several states in a region, compacts which allow water quality monitoring and research to be conducted on an interstate basis can frequently produce more consistent and useful data. The experience of existing compacts indicates one could expect compacts dealing with energy facility siting to carry out this function successfully. 


\section{Resource Planning}

There have been several compacts established whose major purpose was conducting resource planning or allocation (e.g.,.CRC, TRPA). In regions where these activities are currently being done on an individual state basis, an interstate agreement which calls for regional planning would be an improvement. This is particularly true for energy facility planning, very little of which has been done on a regional basis. Regional allocation of scarce resources required by energy facilities would be an important and innovative activity which could be expected to be facilitated by interstate compacts.

\section{Standard-Setting}

Compacts could potentially make significant contributions toward promoting consistency among the environmental standards in a region which would likely be impacted by new energy facilities. Consistency among standards can help avert or defuse interstate disputes in some cases. For instance, problems may arise if the relatively lenient environmental standards in one state allow construction of a plant producing air pollution which is carried by prevailing wind patterns into a neighboring state with higher ambient air quality and more stringent air pollution control regulations. Despite these potential advantages, states have generally been reluctant to delegate standard-setting authority to interstate agencies; thus, one should not expect many compacts to carry out this function.

\section{Permitting}

There are many opportunities within the permitting function for interstate cooperation. Some cooperative programs -- dealing primarily with the permit process - - could be undertaken without a formal, legal compact. - These could include the scheduling of joint hearings by agencies from different states to review a proposed project, and agreements committing agencies from different states to a common decision-making schedule. compacts could be 
structured so that their purpose was just to facilitate the process; it is reasonable to expect compacts to be given this responsibility.

It is much less likely that states would create a compact calling for permits to be issued jointly by several states, or to establish an interstate agency to review applications and grant permits on a regional basis; to date, states have been very reluctant to delegate this responsibility.

\section{Enforcement}

In cases where standard-setting or permitting responsibility has been delegated to an interstate agency, enforcement authority has also usually been delegated. Since it is reasonable from a management perspective for an agency to enforce its own regulations, this seems to be a good policy. However, states do not always provide the funds necessary for interstate agencies to carry out a full enforcement program. The resources of the interstate agency would be more productive in some cases if they were supplemented by personnel from state regulatory agencies or Attorney Generals' staffs. While delegating enforcement authority to an.interstate agency may help ensure that compliance monitoring, inspection, and other enforcement activities are carried out consistently within a region, this function requires substantial resources which must be provided.

In summary, al though there is potential benefit from interstate compacts conducting each element of facility siting programs, much of this potential must be qualified by consideration of which functions states are actualiy willing to delegate. As noted, interstate agencies have shown themselves capable of conducting state-of-the-art research and monitoring, and states have been willing to support them in this area. On the other hand, the ability of interstate agencies to conduct standard-setting depends largely on the states' willingness to delegate resources and authority to enforce their plans and statutes. 
In the areas of standard-setting and permitting, compacts have only limited potential for promoting consistent standards or expediting the permit process as long as states are only willing to delegate authority to conduct the procedural aspects of these functions (facilitating and comment on permit applications, conducting background research to support new standards) rather than more substantive responsibility and authority (actua] granting of permits and enacting standards). Regional enforcement programs can be effective if they receive the required level of support. 


\section{FEDERAL INVOLVEMENT IN INTERSTATE COMPACTS}

As was discussed in Chapter $V$, there are potential benefits of involving interstate compacts in energy facility siting. The Federal government now provides initial approval for all existing interstate compacts and partial ongoing support for most of them, and could play a role in encouraging existing or new compacts to address energy facility issues.

This chapter will briefly discuss two aspects of the Federal support issue: (1) general criteria which can indicate whether a compact is likely to be effective, and therefore worth supporting, and (2) the mechanisms which the Federal government could use to encourage compacts to address the siting issue.

\section{A. Criteria for Federal Support}

As was discussed in the previous chapter, certain underlying conditions seem to be present in the more effective compacts. Federal authorities may want to encourage the adoption of these conditions, or use them as criteria to determine whether a compact is worth supporting. At a minimum, the existing compacts indicate that the following three criteria are very important:

\section{Consistent Goals and Policies}

States belonging to either an existing or new interstate compact receiving Federal support to conduct energy facility siting activities should share reasonably consistent priorities and goals with respect to economic and energy development and environmental protection.

\section{Clear and Strong Mandate}

The purpose of each compact should be clear and well-understood by all member states, and spelled out clearly in the compact itself. To ensure 
that compacts can effectively carry out energy facility siting tasks; they should be urged to assume as much responsibility as possible for implementing their policies and plans through the standard-setting, permitting, and enforcement activities. (i.e., not be just a monitoring and research group).

\section{Technical Staff Expertise}

Interstate agencies must ensure the credibility of their research, monitoring, and planning activities by maintaining a capable and well-managed technical staff. The staff must not be just "part-time."

Although application of these criteria obviously cannot ensure that a compact will effectively expedite the permitting process for new energy facilities, these criteria should help screen out those interstate agencies with little chance of success.

\section{B. Potential Federal Role}

There are some interstate activities which the Federal government may be better able to encourage than others, and these are not necessarily the same activities where compacts could yield the greatest real benefits. Therefore, the limits on Federal leverage in various areas should be considered.

The examination of existing compacts presented in Chapters III and IV shows that states have been very willing to accept Federal support for interstate agencies to conduct basic monitoring or research into environmental. or technical issues. Support mechanisms such as the EPA programs authorized by $\$ 208$ of the Federal Water Pollution Control Act have effectively used Federal funds as an incentive to induce interstate agencies to perform work within certain Federal guidelines. The Federal government (sometimes acting through Federal court decisions) has also been successful in promoting planning for or a110cation of interstate resources (e.g., water use allocation by the CRC, water quality management by ORSANCO). 
On the other hand, the constitution prohibits direct Federal involvement in internal state programs and policies (e.g., state taxes, state government organizations, state regulatory procedures). This places limits on the Federal government's ability to provide incentives to interstate agencies to conduct standard-setting, permitting, and enforcement. Nevertheless, some incentives are possible in these areas.

Given that interstate agencies do have some: potential for addressing energy facility issues, DOE or other Federal agencies may wish to adopt a policy of encouraging new and existing compacts to take advantage of this potential. There are three general mechanisms which Federal agencies could use to encourage and support compacts oriented toward energy facility siting.

\section{Federal Funds}

A program could be estabijished to provide financial assistance to interstate agencies which conduct planning and permitting associated with the siting of energy facilities. Several somewhat similar programs currently exist (e.g., $\$ 106$ of Clean Air Act, $\$ 208$ of Federal Water Pollution Control Act) which provide funds to interstate agencies to support activities in the areas of air quality planning and waste management.

\section{Federal Technical Assistance}

Federal agencies, perhaps acting through Federal Regional Councils or Regional Offices, could provide educational services or technical support in the area of energy facility siting to existing interstate agencies, or groups of states thinking about forming compacts to address the siting problem. Examples would include furnishing information from DOE Regional Offices on new energy facilities planned in an area; providing information from Department of the Interior agencies such as the U.S. Geological Survey, Bureau of Land Management, and Fish and Wildifife Service on natural characteristics such as drainage patterns, land use and wildlife, which could support environ- 
mental impact analyses; and furnishing guidance on the approaches (including organization and procedures) which might be used to maximize the likelihood of success.

\section{Modification of Relevant Regulations}

Federal agencies have the authority under $\$ 110$ of the clean Air Act and similar sections of other legislation to dictate the contents of acceptable state implementation $p l a n s$ (SIPS). Under these types of authority, requirements could be included that in some situations, states must establish interstate organizations to address energy and environmental issues on a regional basis.

These three possible courses of action provides a framework for developing detailed approaches to encouraging compacts to address the siting question. Within each of these approaches, important decisions must be made concerning the degree to which Federal authorities wish to dictate specific functions which compacts must undertake in order to receive support. Those decisions are critical to the development of specific approaches to encouraging compacts. 


\section{Bibliography}

An Act Granting the Consent of Congress to a Great Lakes Bas in Compact, and for Other Purposes (P.L. 90-419), 90th Congress, S. 660, July 24, 1968.

An Act Granting the Consent of Congress to an Interstate Compact Relating to Control and Reduction of Pollution in the Ohio River Orainage Basin (P.L. 76-739), 76th Congress, S. 3617, July 11, 1940.

An Act to Grant the Consent of the Congress to the Tahoe Regional Planning Compact, to Authorize the Secretary of the Interior and Others to Cooperate with the Planning Agency Thereby Created, and for Other Purposes (P.L. 91 148), 91 st Congress, S. 118, December 18, 1969.

Arizona v. California et al., 283 U.S. 423 (1931).

Arizona v. California et al., 292 U.S. 341 (1934).

Arizona v. California et al., 298 U.S. 558 (1936).

Clean Air Act as Amended August 1977 (P.L. 95-11), 95th Congress, August, 1977.

Colorado Revised Statutes, "Colorado River Compact," CRS 1973, 37-61-101.

Federal Water Pollution Control Act (P.L. 92-500) as Amended by the Clean Water Act of 1977 (P.L. 95-217).

Glenn, Thomas R., "Implications of Industrial Pretreatment," delivered at a Symposium on Management Alternatives for Municipal Sludge presented by the Water Resources Division of the New Jersey Department of Environmental Protection, December 1, 1977.

Great Lakes Commission, "Great Lakes Commission Bylaws," June, 1973.

....., "The Great Lakes Commission ... What It Is ... What It Does ... How It Works for You," 1975.

Interstate Sanitation Commission, "Interstate Sanitation Commission -- 1978," January, 1979.

-.--, "New York - New Jersey Metropolitan Area Sewage Sludge Disposal Management Program," October, 1976.

-.--, "Revision of the Tri-State Compact," October, 1970.

-.---, "Tri-State Compact for Pollution Abatement," January, 1936.

-..-., "Water Quality Regulations," October, 1977.

New England Interstate Water Pollution Control Comission, "New England Interstate Water Pollution Control Compact," July, 1947.

--.-., "1977 Annual Report," October, 1977. 
Ohio River Valley Water Sanitation Commission, "Bylaws of the Ohio River Valley Water Sanitation Commission," January, 1976.

-..-., "Ohio River Valley Water Sanitation Compact," June, 1948.

-.---, "ORSANCO in Review -- 1978," June, 1978.

-----, "The Siting of Major Energy-Related Facilities in the Ohio River Corridor -Discussion Paper," prepared for the Task Force on Major Facility Siting, September, 1979.

-..--, "State and Federal Regulations Affecting the Siting of Major Energy-Related Facilities -. Background Paper," prepared for the Task Force on Major Facility Siting, September 1979.

Schroeder, Christopher, "Interstate Compacts to Address Multi-State Permitting and Regulatory Problems Associated with Synfuels Development," July, 1979.

Tahoe Regional Planning Agency, "Tahoe Regional Planning Agency -- An Overview," September, 1975.

U.S. Department of Energy, "Policy Study -- Permitting Process Problems," interoffice memorandum from Obra S. Kernodle, III; to G. Curtis Jones, Jr:, July, 1979.

-.--., "Responses to Questionnaire for Coal-Fired Power Plant Survey -- Boardman Coal Plant," July, 1979.

-..--, "Responses to Questionnaire for Coal-Fired Power Plant Survey -- Colstrip III and IV Plants," July, 1979.

-...-., "Responses to Questionnaire for Coal-Fired Power Plant Survey -- Rush Island Station Plant," July, 1979.

Western Federal Regional Council, "Federal Policy for the Lake Tahoe Basin," August, 1978.

Wiggins, Lyna L. and Daniel T. Wormhoudt, assisted by Christopher Schroeder, "Siting Coal-Fired Power Plants," December, 1978.

Witmer, T. Richard, Ed.; Documents on the Use and Control of the Waters of Interstate and International Streams: Compacts, Treaties, and Adjudications. 2nd ed. Washington, D.C.: U.S. Government Printing Office, 1968. 


\section{ams}

American

Management

Systems, Inc.

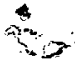

Corporate and

Eastern Regional Offices

1515 Wilson Boulevard

Arlington, Virginia 22209

(703) 841-6000

Washington, D.C. Office

815 15th Street, N.W.

Washington, D.C. 20005

(202) $347-7550$

New York Area Office

111 John Street

New York, New York 10038

(212) 233-1500

Detroit Area Office

3001 West Big Beaver Road

Troy, Michigan 48084

(313) 643-4900

Midwestern Regional Office

120 South Riverside Plaza

Chicago, Illinois 60606

(312) 648-5555

Western Regional Office

561 Pilgrim Drive

San Mateo, California 94404

(415) 573-9481

Computer and

Micromation Centers

1901 North Moore. Street

Arlington, Viginia 22209

(703) $841-6200^{\circ}$ 